\title{
Identification of roselle varieties through simple discriminating physicochemical characteristics using multivariate analysis
}

\author{
Alé KANE ${ }^{1}$, Nawel ACHIR ${ }^{2}$, Mady $\mathrm{CISSE}^{3}$, Dominique PALLET ${ }^{2,4}$, Mama SAKHO $^{3}$, Manuel DORNIER ${ }^{2 *}$
}

\begin{abstract}
The objective of this work is to study the feasibility of a more objective and rigorous classification of the calices of Hibiscus sabdariffa based on their physicochemical profile. To do so, 19 analyses were carried out on 4 varieties of calices cultivated in Senegal: Vimto, Koor, Thaï and CLT92. Principal component analysis results showed that 15 physicochemical and biochemical parameters could be potentially used to discriminate the varieties of calices. Polyphenolic and anthocyanin contents were anti-correlated to protein content and could be used to differentiate the Vimto/CLT92 and the Koor/Thaï varieties. Within these two clusters, $\mathrm{pH}$ and lipid content could discriminate each variety. Finally, factorial discriminant analysis showed that total anthocyanin content, lipid content and chromaticity $\mathrm{C}^{\star}$ were the 3 parameters enabling the most efficient classification of calices according to variety and led to $100 \%$ classification accuracy.
\end{abstract}

Keywords: Hibiscus sabdariffa L.; discriminant analysis; colour; anthocyanin.

Practical Application: Differentiation of roselle varieties thanks to only 3 selected composition criteria.

\section{Introduction}

Hibiscus sabdariffa L., is a plant belonging to the family of Malvaceae. It is cultivated in many tropical and subtropical areas of Africa, Asia and Central America (Morton, 1987). The calices of this plant are appreciated for their use in beverages, syrups, jams and concentrates (Cissé et al., 2009; Costa-Rocha et al., 2014). The resulting products have an interesting acidity and a bright red color due to the presence of anthocyanins especially delphinidin and cyanidin 3-O-sambubioside (Chang et al., 2012; Cissé et al., 2009; Idham et al., 2012; Março et al., 2011). Their high content in polyphenolic compounds provides them notable antioxidant and free radical scavenging activities (Mohd-Esa et al., 2010; Serrano-Cruz et al., 2013). Currently, the demand for concentrates of $H$. sabdariffa calyx extracts is increasing for the production of natural dyes. Therefore, the culture and trade of the calices of $H$. sabdariffa is becoming an interesting source of income for the whole value chain especially in West African countries because of increasing exportation demand from Europe and North America (Cissé et al., 2009). Many varieties of H. sabdariffa are now cultivated in Senegal with a whole production estimated at around 10,000 $\mathrm{t}_{\text {year }}{ }^{-1}$. The calices prices varied from 0.5 to $2.0 € \mathrm{~kg}^{-1}$. They depend on the organoleptic properties of the product which are strongly correlated with the varieties (Babalola et al., 2001; Bechoff et al., 2014): The Vimto variety gives large and long flowers $(4.5 \times 8.5 \mathrm{~cm})$ with sharp red open sepals; The Koor variety is characterized by smaller conical calices $(3.5 \times 4.5 \mathrm{~cm})$; The Thai variety is characterized by speckled red calices; The CLT 92 variety has blue-purple or dark red colour.
The production yield of these different varieties may vary from 250 to $300 \mathrm{~kg} \mathrm{ha}^{-1}$ of calices except for the Vimto variety with an average of $500 \mathrm{~kg} \mathrm{ha}^{-1}$ (Cissé et al., 2009). The Vimto variety is the most demanded by the beverage industry, because of its high production and its organoleptic features (Cissé et al., 2009; Gueye et al., 2012).

Discrimination of the calices from different varieties is still mainly based on morphological criteria that are not always adapted. Indeed, after harvesting, calices are subjected to deformation, bleaching and fracturing during sun-drying and their conservation. Such modifications make distinguishing the calices of one variety from another harder and reduce the accuracy. This task is obviously even more difficult when the calices are turned into powder before the pigment extraction process (Cissé et al., 2012). So, the aim of the study was to elaborate a more rigorous discrimination method that can be easily applied at different steps of processing. From simple physicochemical and biochemical analyses of the calices of the 4 main varieties of $H$. sabdariffa from Senegal, the markers that could be used to discriminate varieties were identified. To do so, analyses very easy to implement in the African context were chosen and the results obtained were treated by principal components and factorial discriminant analyses. These tools have already showed their relevance in the case of tea, milk, and red wine origin or authenticity discrimination (Hammami et al., 2010; Rodríguez-Delgado et al., 2002; Zhao et al., 2011). 


\section{Materials and methods}

\subsection{Raw material}

Four varieties of $H$. sabdariffa were collected across Senegal between 2012 and 2013. During these two years the average annual temperature was $28.5^{\circ} \mathrm{C}$ and $28.8^{\circ} \mathrm{C}$ and the total annual rainfall was $824 \mathrm{~mm}$ and $775 \mathrm{~mm}$ respectively (World Bank Group, 2017). Five regions were considered: Ziguinchor in the South, Kaolack and Fatick in the Center, Thiès in the West and Louga in the North. Depending on the area and the availability of raw material, 2 to 4 varieties of sun-dried calices were collected per region (Table 1). Three samples of $1 \mathrm{~kg}$ were taken for each variety.

\subsection{Reagents}

All the reagents used were of analytical grade and were purchased from Sigma (L'Isle d'Abeau, France).

\subsection{Determination of major macronutrients}

Analyses for water content, total minerals, lipids and proteins were carried out according to the procedure described in the AFNOR standards (Association Française de Normalisation, 1982). The water content was determined by desiccation at $105^{\circ} \mathrm{C}$ for $2 \mathrm{~h}$ (NF V 03-707). The total minerals were determined after a 3 -hour incineration period at $550{ }^{\circ} \mathrm{C}$ (NF V 76-005). Total lipids were obtained using a Soxhlet extractor with diethyl ether as a solvent (NF V03-905). Protein determination was done according to the Kjeldhal method (NF V03-050), using $5.7 \mathrm{~g}$ of proteins per $\mathrm{g}$ of $\mathrm{N}$ as conversion coefficient.

Total and reducing sugars were determined using the Luff-Schoorl method. Titratable acidity of calices was determined by $\mathrm{pH}$ metric method using $0.1 \mathrm{~N} \mathrm{NaOH}$ solution with $10 \mathrm{~g}$ of dried calices mixed with $90 \mathrm{~mL}$ of deionized water and a $\mathrm{pH}$-meter (TitroLine easy model). Water activities of the samples at $25^{\circ} \mathrm{C}$ were determined using a water activity meter Aqualab CX-2 (Decagon Devices, Pullman, WA). All analyses were made in triplicate.

\subsection{Total anthocyanins}

Total anthocyanin content (TA) was assessed by the $\mathrm{pH}$ differential method at pH 1 and $\mathrm{pH} 4.5$ (Lee et al., 2005). Each absorbance was read against distilled water which acted as the control with a spectrometer (SPECOR 200 Plus, Germany). Concentration was expressed as delphinidin 3-O-xylosylglucoside equivalents (molecular weight $577 \mathrm{~g} \mathrm{~mol}^{-1}$ ). The molar extinction coefficient at $\mathrm{pH} 1$ and $510 \mathrm{~nm}$ used for calculation was $26000 \mathrm{~L} \mathrm{~mol}^{-1} \mathrm{~cm}^{-1}$ (Cissé et al., 2012).

Table 1. Location and number of samples collected of Hibiscus sabdariffa L. calices ( $1 \mathrm{~kg}$ dried calices per sample).

\begin{tabular}{lcccccc}
\hline \multirow{2}{*}{ Varieties } & \multicolumn{5}{c}{ Location and number of samples } & \multirow{2}{*}{ Total } \\
\cline { 2 - 6 } & Kaolack & Fatick & Ziguinchor & Thiès & Louga & \\
\hline Koor & 3 & 3 & 3 & 3 & 3 & 15 \\
Vimto & 3 & 3 & 3 & 3 & 3 & 15 \\
Thaï & 3 & 3 & 3 & - & 3 & 12 \\
CLT92 & 3 & - & 3 & - & - & 6 \\
\hline
\end{tabular}

\subsection{Total phenolic content}

The extraction was performed with $0.5 \mathrm{~g}$ of calyx powder in $10 \mathrm{~mL}$ of a mixture of acetone/ water/formic acid (70/28/2 v/v/v) for $10 \mathrm{~min}$. The total phenolic content (TPC) was determined by the Folin-Ciocalteu method optimized by Georgé et al. (2005). The absorbance was measured at $760 \mathrm{~nm}$ with a UV spectrophotometer 7200 Analytik Jena (Germany). Results were expressed as mg of gallic acid equivalent (GAE) per $100 \mathrm{~g}$ of dry matter.

\subsection{Vitamin C}

Ascorbic acid was assessed by HPLC according to Dhuique-Mayer et al. (2007). A 10 g sample was weighed and homogenized with $40 \mathrm{~mL}$ of metaphosphoric acid solution at $45 \mathrm{~g} \mathrm{~L}^{-1}$. After centrifugation, the supernatant was filtered through a $0.45 \mu \mathrm{m}$ membrane and analyzed by HPLC (AGILENT 1100) with an RP18e Licrospher 100 column $(250 \mathrm{~mm} \times 4.6 \mathrm{~mm} ; 5 \mu \mathrm{m}$, Merck, Darmstadt, Germany) and detection at $254 \mathrm{~nm}$. The elution was isocratic $\left(\mathrm{H}_{2} \mathrm{SO}_{4} 0.1 \mathrm{gL}^{-1}\right)$ at a flow rate of $0.8 \mathrm{~mL} \mathrm{~min}$. Quantification of ascorbic acid was done by the external standard method (calibration curve between 20 and $200 \mathrm{mg} \mathrm{L}^{-1}$ ).

\subsection{Free and total amino acids}

\section{Extraction}

Free amino acids: Free amino acids were analyzed following the method used by Moore et al. (1958) with modifications. Briefly, $200 \mathrm{mg}$ of the sample was weighed and placed in a sealable test tube and $50 \mu \mathrm{L}$ of internal standard norleucine $25 \mu \mathrm{M}$ and $4.95 \mathrm{~mL}$ of citrate buffer ( $\mathrm{pH}$ 2.2) were added. The solution was mixed for $1 \mathrm{~h}$ on a rotational shaker.

Total amino acids: Total amino acid profile was obtained by putting $15 \mathrm{mg}$ of the sample (corresponding to 6-9 mg of protein) into a hydrolysis tube containing $50 \mu \mathrm{L}$ of norleucine $25 \mu \mathrm{M}$ and $450 \mu \mathrm{L}$ methanesulfonic acid $4 \mathrm{M}$. The tube was flushed with nitrogen, closed and heated at $150{ }^{\circ} \mathrm{C}$ for $2 \mathrm{~h}$. After cooling, $450 \mu \mathrm{L}$ of $\mathrm{NaOH} 4 \mathrm{M}$ was added to the hydrolysate, which was diluted up to $5 \mathrm{~mL}$ with a loading citrate buffer at $\mathrm{pH}$ 2.2.

\section{Analysis}

The extracts for free and total amino acid analyses were filtered using a $0.45 \mu \mathrm{m}$ membrane filter and $20 \mu \mathrm{L}$ were injected into the amino acid analyzer (Biochrom 30+, Biochrom, France), using a lithium cation exchange resin column, ninhydrin derivatization and simultaneous detection at $570 \mathrm{~nm}$ (440 nm for proline). The amino acid separation along the cationic column was obtained with a succession of 4 sodium citrate buffers of increasing $\mathrm{pH}$ (2.6-8.6) and ionic strength (0.2-0.5 M), and an increasing temperature gradient $\left(52-95^{\circ} \mathrm{C}\right)$. The entire process lasted $95 \mathrm{~min}$ per sample, including the resin regeneration phase. A standard solution containing 18 amino acids $\left(2.5 \mu \mathrm{mol} \mathrm{mL} \mathrm{m}^{-1}\right.$ each, except L-cystine, $1.25 \mu \mathrm{mol} \mathrm{mL} \mathrm{m}^{-1}$ ) was used for comparison (Sigma Brand Amino Acids). Internal calibration using norleucine as a standard was used for precise analysis. 


\subsection{Colour determination}

The colour analysis of samples was performed with a colorimeter (Minolta CR/DP 400) according to the colour system CIE-Lab where the $\mathrm{L}^{\star}$ value (brightness) ranges from black (0) to white (100), $\mathrm{a}^{*}$ value ranges from green $(-60)$ to red $(+60)$ and the $b^{*}$ value ranges from blue $(-60)$ to yellow $(+60)$. The colorimeter was calibrated against a standard white reference tile. Samples were placed in a clear glass Petri dish (10 replicates), and colour measurements were done in triplicate. The chroma or saturation value $\left(\mathrm{C}^{\star}\right)$ and the hue angle $\left(\mathrm{h}^{\circ}\right)$ were calculated by Equations 1 and 2 .

$$
\begin{aligned}
& C^{*}=\sqrt{a^{*^{2}}+b^{*^{2}}} \\
& h^{\circ}=\tan ^{-1}\left(\frac{a^{*}}{b^{*}}\right)
\end{aligned}
$$

\subsection{Statistical analysis}

Analysis of variance was performed using XLSTAT Release 10 (Addinsoft, Paris, France). Tukey's multiple range tests was applied to obtain comparisons among means. Evaluations were based on the $\mathrm{P}<0.05$ significance level. Multivariate analyses were performed by principal component analysis (PCA) and factorial discriminant analysis (FDA) using XLSTAT software.

\section{Results and discussion}

\subsection{Physicochemical and biochemical characteristics}

For all 4 varieties, the physicochemical characteristics and the composition of the calices were not significantly different as a function of the production area. Therefore, the main differences between calices are rather due to the variety than to the growing or climate conditions. Table 2 presents the average values of the physicochemical and biochemical characteristics calculated with the different culture areas for the 4 varieties of calyx, Vimto, Koor, Thai and CLT92.

The analysis of variance showed significant differences $(\mathrm{P}<0.05)$ in the composition of the calices as a function of the variety. Indeed, the only 4 parameters not significantly different were dry matter, total ash, titratable acidity and vitamin $\mathrm{C}$ content with average values of $914 \mathrm{~g} \mathrm{~kg}^{-1}, 62 \mathrm{~g} \mathrm{~kg}^{-1}, 277 \mathrm{mEq} \mathrm{kg}{ }^{-1}$ and $412 \mathrm{mg} \mathrm{kg}^{-1}$ respectively. Water activity varied a little but was very low from 0.42 to 0.49 as expected and is not supposed to be a discriminative parameter. These results are in agreement with the literature data (Bechoff et al., 2014; Cissé et al., 2009; Suliman, 2011).

The value of luminosity $L^{\star}$ is on average 38.3 . The greatest $\mathrm{L}^{\star}$ value is for the Koor and Thai varieties while Vimto showed the weakest. The intensity of the red colouring, usually assessed by $\mathrm{a}^{\star}$ value, is sometimes used for calyx variety discrimination (Cissé et al., 2009). In our study, $a^{\star}$ value varied very little between the varieties Vimto, Koor and Thai with an average value of 29. It was substantially lower for CLT92. The $b^{*}$ value was significantly higher for the Koor and Thai varieties. The index of chromaticity $\mathrm{C}^{\star}$ which measures the colour saturation was the highest for the Vimto variety followed by that of the Koor and Thai varieties and finally CLT92. The differences observed for all colour parameters highlighted the diversity of calices and their potential in the production of colouring agents.

Whatever the variety, the acidity of the calyx was high with an average $\mathrm{pH}$ of 2.25 . The Koor calices had the strongest acidity

Table 2. Physicochemical and biochemical characteristics of the main varieties of Hibiscus sabdariffa L. calices cultivated in Senegal (mean and

\begin{tabular}{|c|c|c|c|c|}
\hline Characteristics & $\begin{array}{l}\text { VIMTO } \\
(\mathrm{n}=45) \\
\end{array}$ & $\begin{array}{c}\text { KOOR } \\
(\mathrm{n}=45)\end{array}$ & $\begin{array}{c}\text { THAI } \\
(\mathrm{n}=36)\end{array}$ & $\begin{array}{c}\text { CLT92 } \\
(\mathrm{n}=18)\end{array}$ \\
\hline $\mathrm{pH}$ & $2.28^{\mathrm{a}}(0.10)$ & $2.17^{\mathrm{b}}(0.11)$ & $2.27^{\mathrm{a}}(0.07)$ & $2.36^{\mathrm{a}}(0.05)$ \\
\hline Water activity (Aw) & $0.42^{\mathrm{b}}(0.02)$ & $0.45^{\mathrm{a}}(0.04)$ & $0.49^{\mathrm{b}}(0.03)$ & $0.44^{\mathrm{b}}(0.06)$ \\
\hline $\mathrm{L}^{*}$ & $32.7^{\mathrm{d}}(1.5)$ & $42.6^{\mathrm{a}}(1.6)$ & $40.3^{\mathrm{b}}(1.5)$ & $37.7^{c}(2.5)$ \\
\hline$a^{*}$ & $30.04^{\mathrm{a}}(1.09)$ & $29.32^{\mathrm{a}}(1.20)$ & $27.96^{\mathrm{b}}(1.02)$ & $21.86^{\mathrm{c}}(3.03)$ \\
\hline$b^{*}$ & $7.46^{\mathrm{b}}(0.81)$ & $8.71^{\mathrm{a}}(0.53)$ & $8.22^{\mathrm{a}}(0.68)$ & $7.25^{\mathrm{b}}(0.63)$ \\
\hline $\mathrm{C}^{*}$ & $30.96^{\mathrm{a}}(1.12)$ & $30.59^{\mathrm{a}}(1.21)$ & $29.15^{\mathrm{b}}(0.95)$ & $23.03^{c}(3.07)$ \\
\hline $\mathrm{h}^{\circ}$ & $0.24^{c}(0.03)$ & $0.29^{\mathrm{b}}(0.02)$ & $0.29^{\mathrm{b}}(0.03)$ & $0.32^{\mathrm{a}}(0.02)$ \\
\hline \multicolumn{5}{|l|}{ Global composition } \\
\hline Dry matter $\left(\mathrm{g} \mathrm{kg}^{-1}\right)$ & $916(12)$ & $917(7)$ & $906(17)$ & $914(12)$ \\
\hline Total ash $\left(\mathrm{g} \mathrm{kg}^{-1}\right)$ & $59.9(6.2)$ & $66.7(10.3)$ & $56.5(5.0)$ & $62.8(5.7)$ \\
\hline Proteins $\left(\mathrm{g} \mathrm{kg}^{-1}\right)$ & $92.5^{\mathrm{c}}(4.3)$ & $103.5^{\mathrm{b}}(3.1)$ & $108.0^{\mathrm{a}}(4.1)$ & $93.1^{\mathrm{c}}(3.1)$ \\
\hline Free amino acids $\left(\mathrm{g} \mathrm{kg}^{-1}\right)$ & $11.6^{\mathrm{c}}(8.0)$ & $20.1^{\mathrm{b}}(4.1)$ & $25.2^{\mathrm{a}}(4.7)$ & $12.1^{\mathrm{c}}(1.4)$ \\
\hline Total amino acids $\left(\mathrm{g} \mathrm{kg}^{-1}\right)$ & $40.2^{\mathrm{b}}(3.6)$ & $54.7^{\mathrm{a}}(10.5)$ & $61.9^{\mathrm{a}}(9.9)$ & $42.6^{\mathrm{b}}(6.1)$ \\
\hline Total sugars $\left(\mathrm{g} \mathrm{kg}^{-1}\right)$ & $101.1^{\mathrm{a}}(11.3)$ & $81.4^{\mathrm{b}}(10.9)$ & $74.7^{\mathrm{b}}(10.4)$ & $98.4^{\mathrm{a}}(8.1)$ \\
\hline Reducing sugars $\left(\mathrm{g} \mathrm{kg}^{-1}\right)$ & $83.8^{\mathrm{a}}(12.0)$ & $65.5^{\mathrm{b}}(10.6)$ & $51.3^{\mathrm{c}}(7.4)$ & $90.9^{\mathrm{a}}(7.4)$ \\
\hline Total lipids ( $\mathrm{g} \mathrm{kg}^{-1}$ ) & $6.6^{c}(0.4)$ & $5.7^{\mathrm{d}}(0.5)$ & $8.7^{\mathrm{a}}(0.5)$ & $7.6^{\mathrm{b}}(0.4)$ \\
\hline Titratable acidity $\left(\mathrm{mEq} \mathrm{kg}{ }^{-1}\right)$ & $271.8(47.3)$ & $299.9(29.8)$ & $272.9(24.8)$ & $265.0(22.9)$ \\
\hline Total phenolic content $\left(\mathrm{g} \mathrm{GAE} \mathrm{kg}^{-1}\right)$ & $28.2^{\mathrm{a}}(2.2)$ & $20.7^{\mathrm{b}}(2.8)$ & $19.3^{\mathrm{b}}(3.2)$ & $25.2^{\mathrm{a}}(3.9)$ \\
\hline Total anthocyanins $\left(\mathrm{g} \mathrm{kg}^{-1}\right)$ & $16.3^{\mathrm{a}}(1.8)$ & $8.2^{\mathrm{b}}(2.3)$ & $8.2^{\mathrm{b}}(3.0)$ & $17.3^{\mathrm{a}}(2.7)$ \\
\hline Vitamin $\mathrm{C}\left(\mathrm{mg} \mathrm{kg}^{-1}\right)$ & $400.3(49.4)$ & $425.7(54.0)$ & $407.9(39.5)$ & $416.8(35.8)$ \\
\hline
\end{tabular}
standard deviation of $\mathrm{n}$ repetitions. Means with different letters in the same line were significantly different at $\mathrm{P}>0.05$ ). 
with a $\mathrm{pH}$ value of 2.17 and a titratable acidity of $300 \mathrm{mEq} \mathrm{kg}{ }^{-1}$ (higher but not significantly different from the other varieties). This corresponds to $20 \mathrm{~g} \mathrm{~kg}^{-1}$ of malic acid which is assumed to be the main organic acid in calices (Cissé et al., 2009). This value is relatively high in comparison with $12 \mathrm{~g} \mathrm{~kg}^{-1}$ found for dried grapes (Mahmutoğlu et al., 1996) or dried apples $\left(4-8 \mathrm{~g} \mathrm{~kg}^{-1}\right)$. This result is interesting since it is known that anthocyanins are more stable in acidic conditions.

The total lipid content was higher in the Thai variety calices with values exceeding $8 \mathrm{~g} \mathrm{~kg}^{-1}$. The lowest lipid content was found for the Vimto and Koor varieties which is in accordance with literature where low lipid content was found in varieties cultivated in Sudan (Suliman, 2011). The highest protein, total and free amino acid contents were also found for the Thai variety, equalled or followed by the Koor variety. In average, free amino acids represented 30 to $40 \%$ of the total amino acids.

The varieties CLT92 and Vimto contained the highest total and reducing sugar contents. They also had the highest concentrations in total anthocyanins and polyphenols. These results are coherent with previous works (Cissé et al., 2009). The anthocyanin content was 2 fold-higher in both varieties $\left(17 \mathrm{~g} \mathrm{~kg}^{-1}\right)$ than in Thai and Koor $\left(8 \mathrm{~g} \mathrm{~kg}^{-1}\right)$. It is interesting to note that these values were not correlated with $\mathrm{a}^{\star}$-values variations.

The physicochemical analyses showed interesting differences between the four varieties. It is therefore possible to study the correlations between these parameter variations.

\subsection{Principal component analysis}

Principal component analyses (PCA) were performed on the results of all samples that is to say 15 samples for Koor and Vimto, 12 for Thai and 6 for CLT92 (Table 1). The analysis of the eigenvalues showed that the components F1, F2 and F3 synthetized $74 \%$ of variability information. A projection can thus be carried out on the axes F1 and F2 which account for $62 \%$ of variability (Figure 1A) and on the axes F1 and F3 which account for 55\% of variability (Figure 1B). The results of the analysis of the matrix
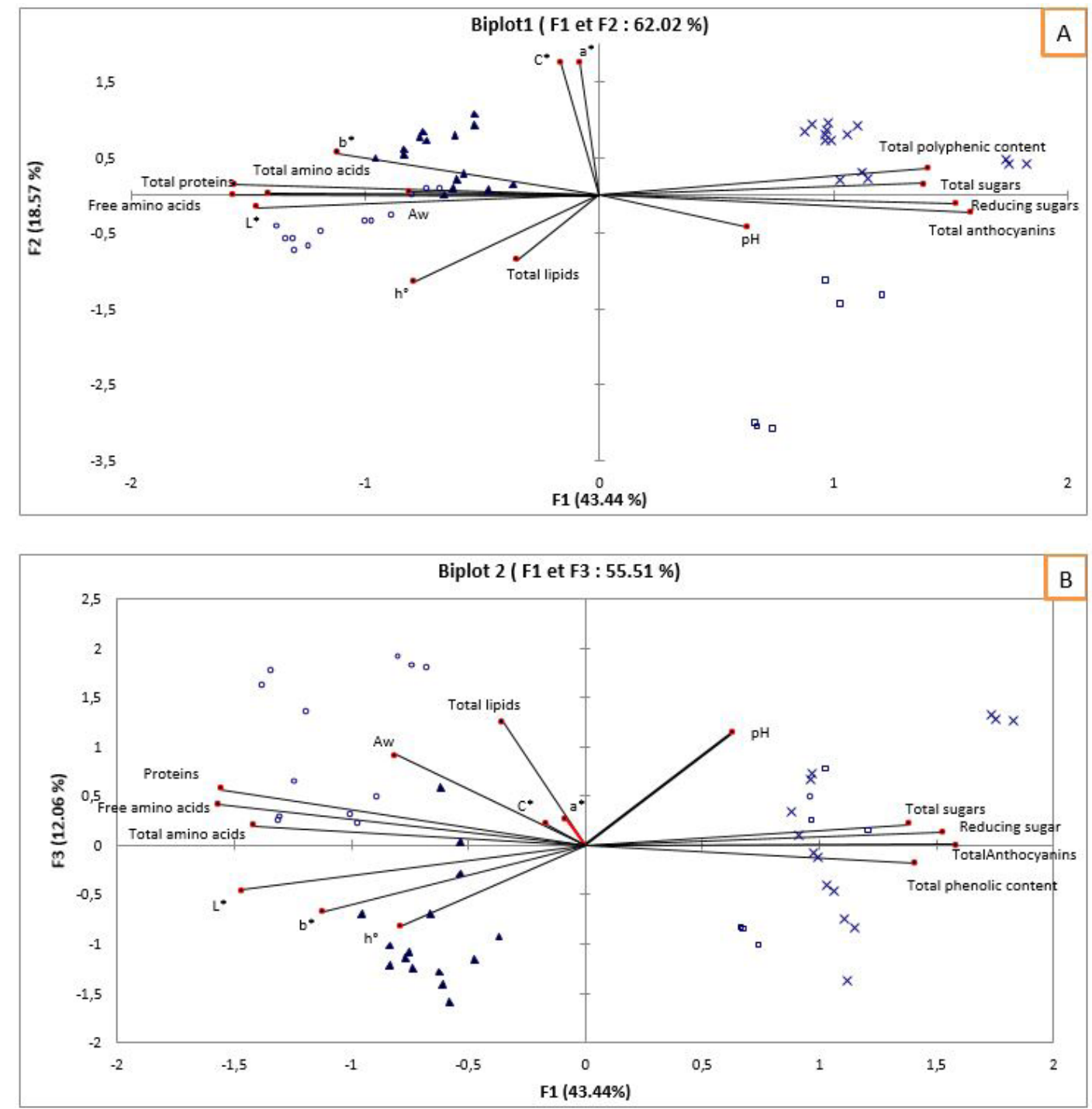

Figure 1. Biplot of variable and individual projections from principal component analysis of Hibiscus sabdariffa L. calyx compositions of the 4 varieties Vimto $(\times)$, Thai (o), CLT92 ( $\square$ ) and Koor $(\boldsymbol{\Delta})$, (A) projection on F1 and F2 and (B) projection on F1 and F3. 
Table 3. Correlation Matrix (Pearson) of the analytical data of Hibiscus sabdariffa calyx samples.

\begin{tabular}{|c|c|c|c|c|c|c|c|c|c|c|c|c|c|}
\hline Variables & 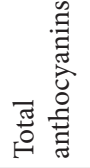 & 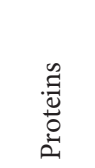 & 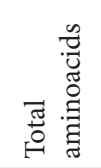 & 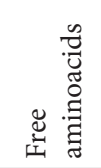 & 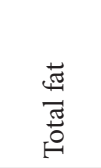 & 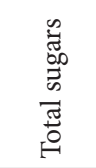 & 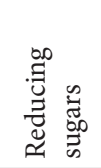 & 壳 & $\stackrel{\star}{\lrcorner}$ & ${ }_{\varpi}^{\star \star \sigma}$ & ڤ & ${ }^{\star}$ & $\stackrel{\star}{\beth}$ \\
\hline Total phenolic content & 0.831 & -0.741 & -0.611 & -0.768 & -0.197 & 0.529 & 0.498 & 0.289 & -0.682 & 0.174 & -0.120 & 0.160 & -0.234 \\
\hline Total anthocyanins & & -0.783 & -0.723 & -0.830 & -0.038 & 0.594 & 0.670 & 0.380 & -0.740 & -0.143 & -0.415 & -0.169 & -0.189 \\
\hline Proteins & & & 0.707 & 0.835 & 0.280 & -0.593 & -0.668 & -0.098 & 0.668 & 0.155 & 0.408 & 0.182 & 0.169 \\
\hline Total aminoacids & & & & 0.898 & 0.252 & -0.356 & -0.644 & -0.360 & 0.506 & 0.039 & 0.367 & 0.065 & 0.225 \\
\hline Free aminoacids & & & & & 0.331 & -0.453 & -0.668 & -0.279 & 0.631 & 0.054 & 0.339 & 0.078 & 0.197 \\
\hline Total lipids & & & & & & -0.150 & -0.239 & 0.341 & -0.060 & -0.330 & -0.241 & -0.340 & 0.085 \\
\hline Total sugars & & & & & & & 0.796 & 0.182 & -0.600 & 0.033 & -0.646 & -0.018 & -0.542 \\
\hline Reducing sugars & & & & & & & & 0.375 & -0.574 & -0.107 & -0.657 & -0.154 & -0.416 \\
\hline $\mathrm{pH}$ & & & & & & & & & -0.344 & -0.119 & -0.295 & -0.138 & -0.110 \\
\hline$L^{*}$ & & & & & & & & & & -0.081 & 0.572 & -0.035 & 0.535 \\
\hline$a^{*}$ & & & & & & & & & & & 0.318 & 0.997 & -0.643 \\
\hline$b^{*}$ & & & & & & & & & & & & 0.387 & 0.518 \\
\hline $\mathrm{C}^{*}$ & & & & & & & & & & & & & -0.585 \\
\hline $\mathrm{h}^{\circ}$ & & & & & & & & & & & & & \\
\hline
\end{tabular}

of correlation highlighted various relations between the analyzed variables (Table 3). The biplot of the principal components in Figure 1A showed that the amino acids, proteins, polyphenols, anthocyanins, total and reducing sugars and lightness contributed to approximately $85 \%$ of the F1 component. Some correlations were very logical. Indeed, anthocyanin concentration was correlated to polyphenol content, reducing sugars to total sugar, aminoacids to proteins. More interestingly, total and reducing sugars exhibited positive correlations with anthocyanins and polyphenols and all these parameters were anti-correlated to amino acid and protein contents. $\mathrm{a}^{\star}$ and $\mathrm{C}^{\star}$ values presented a contribution higher than $68 \%$ on the F2 component and were therefore not correlated to the previous parameters. $\mathrm{PH}$, total lipids and the other color parameters were not correctly projected either on F1 nor F2. Therefore these variables were observed in Figure 1B. PH, $\mathrm{h}^{\circ}$ and $\mathrm{b}^{*}$ values did not present interesting correlations and were not properly projected either on F1 or F3. Total lipids presented a more significant contribution on F3.

The projection of the individuals in Figure 1A showed two groups along F1 axe with close physicochemical characteristics: the Thai and Koor varieties on one hand and the Vimto and CLT92 varieties on the other. The Thai and Koor varieties are characterized by their amino acid and protein contents while Vimto and CLT92 by their strong contents in anthocyanins, polyphenols and sugars. This is consistent with works by Cissé et al. (2009) that showed that the CLT92 variety recently introduced in Senegal presented similarities with the Vimto variety. Interestingly, the Vimto and CLT92 varieties could be discriminated by $\mathrm{C}^{\star}$ values (Figure 1A) and the Thai and Koor varieties by their lipid content. The PCA allowed the discriminant characteristic of the varieties to be identified as well as the redundancies (i.e. the correlated parameters).

\subsection{Factorial discriminant analysis}

The results obtained in the PCA highlighted clear trends in the physicochemical characteristics between the various varieties of calices of $H$. sabdariffa that could be used to discriminate
Table 4. Confusion matrix resulting from AFD for the discrimination of varieties of Hibiscus sabdariffa L. calices.

\begin{tabular}{ccccccc}
\hline From \To & CLT92 & Koor & Thaï & Vimto & Total & \% correction \\
\hline CLT92 & 6 & 0 & 0 & 0 & 6 & 100 \\
Koor & 0 & 12 & 0 & 0 & 12 & 100 \\
Thaï & 0 & 0 & 12 & 0 & 12 & 100 \\
Vimto & 0 & 0 & 0 & 12 & 12 & 100 \\
Total & 6 & 12 & 12 & 12 & 42 & 100 \\
\hline
\end{tabular}

them. Factorial discriminant analysis (FDA) was therefore run on different combinations of non-correlated parameters. The simplest parameters to measure were chosen in the case of the multicollinearities: anthocyanins instead of polyphenols, total sugars instead of reducing sugars, proteins instead of amino acids. FDA was used on two experimental data sets. The first, corresponding to the samples taken in the 4 areas, Kaolack, Fatick, Ziguinchor and Louga, was used to carry out the discrimination of the varieties. The second, corresponding to the calices of the Vimto and Koor varieties coming from Thiès, was used to validate the prediction of discrimination.

All parameter combinations gave satisfactory results. However, the best result was obtained by using chromaticity $\mathrm{C}^{\star}$, total lipids, proteins and anthocyanin contents. Indeed, these variables made it possible to carry out a classification of the varieties with a yield of $100 \%$ classification accuracy (Table 4). Moreover, prediction samples were classified without any confusion (Figure 2).

Discrimination can also be carried out by using the following parameters: total anthocyanins, total lipids, proteins and $\mathrm{pH}$. This combination enabled a classification of the samples of the Thai and Koor varieties with a success rate of 95\%. However, the calices of the Vimto and CLT92 varieties were sometimes confused. This confusion is due to the close physicochemical compositions between them, as already noted (Cissé et al., 2009). 


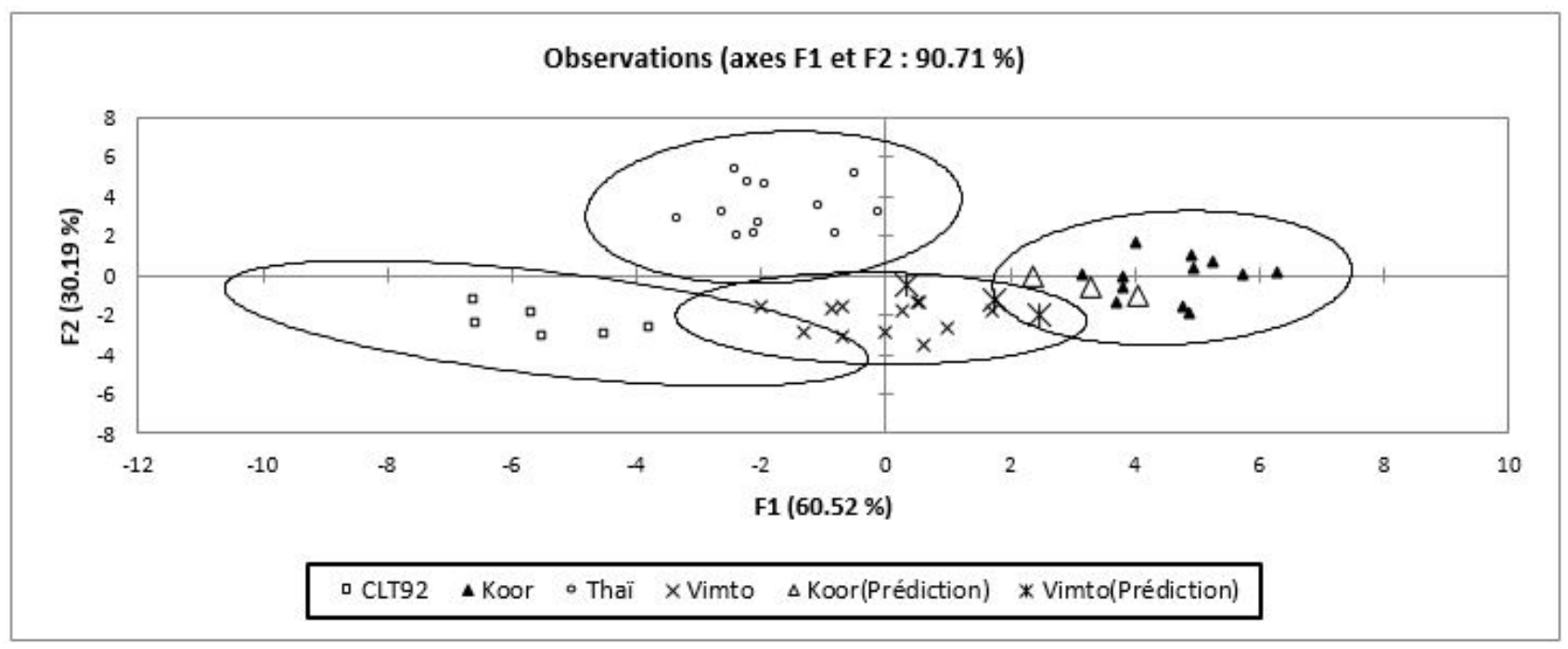

Figure 2. Plot for classification of Hibiscus sabdariffa L. calices using 4 variables: total anthocyanins, total lipids, total proteins and color saturation C* .

\section{Conclusion}

The analysis of variance initially showed that the 4 varieties of calices of H. sabdariffa presented significant differences in composition. Characteristic parameters of each variety were identified by principal components analysis. A combination of parameters that are not correlated and simple to measure allowed a good discrimination between the 4 varieties of calices and lead to a yield of $100 \%$ classification accuracy. Thus, these results showed that the varieties of calices can be authenticated from very basic physicochemical analyses. Further work should be done with other varieties of $H$. sabdariffa and the results should be validated using a greater number of samples. In addition, other finer and specific analyses such as phenolic profile could be of interest in order to differentiate the varieties more accurately.

\section{Acknowledgements}

This work was conducted with financial support from the European Union project (FP7 245-025) called African Food Tradition rEvisited by Research (AFTER) and from CIRAD.

\section{References}

Association Française de Normalisation - AFNOR. (1982). Produits dérivés des fuits et légumes. Paris: AFNOR.

Babalola, S. O., Babalola, A. O., \& Aworh, O. C. (2001). Compositional attributes of the calyces of roselle (Hibiscus sabdariffa L.). Journal of Food Technology in Africa, 6(4), 133-134. http://dx.doi.org/10.4314/ jfta.v6i4.19306.

Bechoff, A., Cissé, M., Fliedel, G., Declemy, A. L., Ayessou, N., Akissoe, N., Touré, C., Bennett, B., Pintado, M., Pallet, D., \& Tomlins, K. I. (2014). Relationships between anthocyanins and other compounds and sensory acceptability of Hibiscus drinks. Food Chemistry, 148, 112-119. PMid:24262534. http://dx.doi.org/10.1016/j.foodchem.2013.09.132.

Chang, X. L., Wang, D., Chen, B. Y., Feng, Y. M., Wen, S. H., \& Zhan, P. Y. (2012). Adsorption and desorption properties of macroporous resins for anthocyanins from the calyx extract of Roselle (Hibiscus sabdariffa L.). Journal of Agricultural and Food Chemistry, 60(9), 2368-2376. PMid:22329796. http://dx.doi.org/10.1021/jf205311v.

Cissé, M., Bohuon, P., Sambe, F., Kane, C., Sakho, M., \& Dornier, M. (2012). Aqueous extraction of anthocyanins from Hibiscus sabdariffa: experimental kinetics and modeling. Journal of Food Engineering, 109(1), 16-21. http://dx.doi.org/10.1016/j.jfoodeng.2011.10.012.

Cissé, M., Dornier, M., Sakho, M., Ndiaye, A., Reynes, M., \& Sock, O. (2009). The bissap (Hibiscus sabdariffa L.): composition and principal uses. Fruits, 64(3), 179-193. http://dx.doi.org/10.1051/ fruits/2009013.

Costa Rocha, I., Bonnlaender, B., Sievers, H., Pischel, I., \& Heinrich, M. (2014). Hibiscus sabdariffa L.: a phytochemical and pharmacological review. Food Chemistry, 165, 424-443. PMid:25038696. http://dx.doi. org/10.1016/j.foodchem.2014.05.002.

Dhuique-Mayer, C., Tbatou, M., Carail, M., Caris-Veyrat, C., Dornier, M., \& Amiot, M. J. (2007). Thermal degradation of antioxidant micronutrients in citrus juice: kinetics and newly formed compounds. Journal of Agricultural and Food Chemistry, 55(10), 4209-4216. PMid:17451252. http://dx.doi.org/10.1021/jf0700529.

Georgé, S., Brat, P., Alter, P., \& Amiot, M. J. (2005). Rapid determination of polyphenols and vitamin C in plant-derived products. Journal of Agricultural and Food Chemistry, 53(5), 1370-1373. PMid:15740008. http://dx.doi.org/10.1021/jf048396b.

Gueye, G., Diop, D., \& Hofmann, P. (2012). Manuel de formation sur le BISSAP (Hibiscus sabdariffa). Dakar: PRODDEL.

Hammami, M., Rouissi, H., Salah, N., Selmi, H., Al-Otaibi, M., Blecker, C., \& Karoui, R. (2010). Fluorescence spectroscopy coupled with factorial discriminant analysis technique to identify sheep milk from different feeding systems. Food Chemistry, 122(4), 1344-1350. http://dx.doi.org/10.1016/j.foodchem.2010.03.107.

Idham, Z., Muhamad, I. I., \& Sarmidi, M. R. (2012). Degradation kinetics and color stability of spray-dried encapsulated anthocyanins from Hibiscus Sabdariffa L. Journal of Food Process Engineering, 35(4), 522-542. http://dx.doi.org/10.1111/j.1745-4530.2010.00605.x.

Mahmutoğlu, T., Emír, F., \& Saygi, Y. B. (1996). Sun/solar drying of differently treated grapes and storage stability of dried grapes. Journal of Food Engineering, 29(3), 289-300. http://dx.doi.org/10.1016/02608774(96)00006-4. 
Março, P. H., Poppi, R. J., Scarminio, I. S., \& Tauler, R. (2011). Investigation of the $\mathrm{pH}$ effect and $\mathrm{UV}$ radiation on kinetic degradation of anthocyanin mixtures extracted from Hibiscus acetosella. Food Chemistry, 125(3), 1020-1027. http://dx.doi.org/10.1016/j.foodchem.2010.10.005.

Mohd-Esa, N., Hern, F. S., Ismail, A., \& Yee, C. L. (2010). Antioxidant activity in different parts of roselle (Hibiscus sabdariffa L.) extracts and potential exploitation of the seeds. Food Chemistry, 122(4), 1055-1060. http://dx.doi.org/10.1016/j.foodchem.2010.03.074.

Moore, S., Spackman, D. H., \& Stein, W. H. (1958). Chromatography of amino acids on sulfonated polystyrene resins. an improved system. Analytical Chemistry, 30(7), 1185-1190. http://dx.doi.org/10.1021/ ac60139a005.

Morton, J. F. (1987). Fruits of warm climates (pp. 281-286). Greensborough: Media Incorporated.

Lee, J., Durst, R. W., \& Wrolstad, R. E. (2005). Determination of total monomeric anthocyanin pigment content of fruit juices, beverages, natural colorants, and wines by the ph differential method: collaborative study. Journal of AOAC International, 88(5), 12691278. PMid:16385975.

Rodríguez-Delgado, M.-Á., González-Hernández, G., Conde-González, J.-E., \& Pérez-Trujillo, J.-P. (2002). Principal component analysis of the polyphenol content in young red wines. Food Chemistry, 78(4), 523-532. http://dx.doi.org/10.1016/S0308-8146(02)00206-6.

Serrano-Cruz, M. R., Villanueva-Carvajal, A., Morales Rosales, E. J., Ramírez Dávila, J. F., \& Dominguez-Lopez, A. (2013). Controlled release and antioxidant activity of Roselle (Hibiscus sabdariffa L.) extract encapsulated in mixtures of carboxymethyl cellulose, whey protein, and pectin. Lebensmittel-Wissenschaft + Technologie, 50(2), 554-561. http://dx.doi.org/10.1016/j.lwt.2012.08.013.

Suliman, A. M. A. (2011). A comparative study on red and white karkade (Hibiscus sabdariffa L.) calyces, extracts and their products. Pakistan Journal of Nutrition, 10(7), 680-683. http://dx.doi.org/10.3923/ pjn.2011.680.683.

World Bank Group. (2017). Climate change knowledge portal for development practioners and policy makers. Retrieved from http:// www.worldbank.org/en/topic/climatechange

Zhao, Y., Chen, P., Lin, L., Harnly, J. M., Yu, L., \& Li, Z. (2011). Tentative identification, quantitation, and principal component analysis of green pu-erh, green, and white teas using UPLC/DAD/MS. Food Chemistry, 126(3), 1269-1277. PMid:25544798. http://dx.doi. org/10.1016/j.foodchem.2010.11.055. 